\title{
Oral Health Knowledge and Habits in Children with Type 1 Diabetes Mellitus
}

\author{
Crésio ALVES ${ }^{1}$ \\ Márcia BRANDÃO2 \\ Juliana ANDION ${ }^{1}$ \\ Rafaela MENEZES ${ }^{1}$ \\ Pediatric Endocrinology Service, University Hospital Professor Edgard Santos, \\ School of Medicine, Federal University of Bahia, Salvador, BA, Brazil \\ Dental School, Bahian School of Medicine and Public Health, Salvador, BA, Brazil
}

\begin{abstract}
This study evaluated the oral health knowledge and habits in Brazilian children with type 1 diabetes mellitus (T1DM). A cross-sectional study was performed between November of 2005 and April of 2006 in a public health university hospital, interviewing 55 diabetic children and 55 non-diabetic control children with a semi-structured questionnaire. As much as $55 \%$ of the diabetic children and $35.5 \%$ of the non-diabetic children were males with mean age of $11.3 \pm 3.7$ years and $11.2 \pm 3.8$ years, respectively. The mean duration of the T1DM was of $4.5 \pm 0.8$ years. Almost half of the diabetic and non-diabetic children brushed their teeth three times a day. Dental floss was used once a day by $30.9 \%$ of diabetics and $18.0 \%$ of control subjects. A total of $27 \%$ of the diabetics $v s .54 .5 \%$ of non-diabetics had gingival bleeding. The dentist was aware of the T1DM in $74.5 \%$ of the cases. As much as $63.8 \%$ of the diabetic subjects had been to the dentist within the previous 12 months. In conclusion, although the diabetic children seemed to have better oral health habits than the control children, there is a need for more information regarding oral hygiene and healthy habits.
\end{abstract}

Key Words: Diabetes mellitus, periodontitis, oral health, public health.

\section{INTRODUCTION}

Type 1 diabetes mellitus (T1DM) is a chronic systemic metabolic disease characterized by an absolute insulin deficient production by the pancreatic beta-cells. This disorder affects mainly children and adolescents. Although these patients are oriented to follow a diet with restricted consumption of sucrose (the most cariogenic of sugars), the lack of knowledge of good oral health habits can lead to poor glycemic control and the onset of morbidities related to oral health (1). Some studies have reported that individuals with diabetes present oral complications more frequently than healhty subjects. The fact that periodontal disease is considered as the 6th more frequent chronic complication of diabetes support these data (2). Therefore, it is important for diabetics to be followed by a multidisciplinary team that includes dentists. Furthermore, it is recommended that educational oral health programs be implemented, targeting patients and their family members.

The aim of the present study was to obtain information about oral health knowledge and habits in children and adolescents with T1DM in the city of Salvador, BA, Brazil.

\section{MATERIAL AND METHODS}

Adescriptive cross-sectional study was conducted between November 2005 and April 2006 at the Pediatric Endocrinology Service of a public university hospital in the city of Salvador, BA, Brazil.

The study sample consisted of 55 T1DM children recruited during routine outpatient treatment and 55 age-matched non-diabetics recruited in a public school. Using a semi-structured questionnaire with multiple-choice closed questions, information was col- 
lected about diagnosis, oral hygiene habits, frequency and consumption of alcohol and tobacco and visits to the dentist. The questionnaire was constructed for this study based on Moore et al. (3) In addition, the participants' household income and educational level was also recorded. The questions were answered by the children under parental supervision. The questionnaire was applied by four previously trained Endocrinology Residents after a preliminary pre-test to assess the consistency of the questions.

The descriptive analysis of the results used mean and standard deviation for continuous variables and proportions for qualitative variables. The statistical analysis was done with the chi-square test for intergroup comparisons. Significance level was set at 5\%. The research project was reviewed and approved by the institutional Research Ethics Committee.

\section{RESULTS}

Fifty-six per cent of the diabetics and 35.5\% of the non-diabetics were males with mean age of $11.3 \pm$ 3.7 years and $11.2 \pm 3.8$ years, respectively. The mean duration of the T1DM was $4.5 \pm 0.8$ years (range: $1-16$ years). The household income was between 1-3 Brazilian minimum wages for $74.5 \%$ of diabetics and $65.5 \%$ of non-diabetics. Most parents of both groups had an incomplete primary education $(72.7 \%$ of diabetics and $81.8 \%$ of non-diabetics).

Consumption of alcoholic beverages was reported by $7.2 \%$ of diabetic children and $9.1 \%$ of non-diabetic children. The minority of diabetics (3.6\%) and no nondiabetic child smoked tobacco.

Eighty-five per cent of the diabetics vs. $70.9 \%$ of the non-diabetics had visited the dentist at least once. More diabetics had been to the dentist within the previous 12 months (63.8\%) than the non-diabetics (48.7\%). Dental treatment was almost always provided at a public health service facility $(59.6 \%$ of diabetics and $89.7 \%$ of non-diabetics). The main reason for the dental visit was: cleaning $(34.0 \%$ of diabetics $v s .46 .2 \%$ of non-diabetics) and caries treatment $(31.9 \%$ of diabetics vs. $23.1 \%$ of non-diabetics). The most commonly mentioned reasons for not visiting the dentist more often were: difficulty in scheduling an appointment (36.1\% of diabetics $v s$. $38.9 \%$ of non-diabetics) and the high treatment costs ( $27.8 \%$ of diabetics $v s .13 .9 \%$ of non-diabetics).

Tooth brushing at least 3 times a day was per- formed by $49.1 \%$ of subjects in both groups, while more diabetics used dental floss at least once a day $(30.9 \%$ vs. $18.2 \%$ ). Toothpaste was used by $100 \%$ of the diabetics and $98.2 \%$ of non-diabetics. With regard to gingival bleeding, more non-diabetics reported bleeding with the use of dental floss (40.0\%) and spontaneously (12.7\%) than diabetics ( $16.4 \%$ and $1.8 \%$, respectively). Gingival bleeding during toothbrushing was reported by $30.9 \%$ of diabetics and $36.4 \%$ of non-diabetics.

In the diabetic group, $49.1 \%$ answered that their oral health would be better if they did not have T1DM and $65.5 \%$ had been informed by a health professional that they should visit the dentist more frequently because of the diabetes. None of them had ever been enrolled in an oral health educational program. Table 1 summarizes the most important findings of the study.

\section{DISCUSSION}

Several studies have demonstrated that periodontal treatment had a positive influence on the metabolic control of diabetics and that the higher glucose content in oral fluids contributes to bacterial proliferation, increasing the formation of dental plaque and leading to periodontal disease (1-4). Diabetics with severe periodontal disease have a higher risk of renal and cardiovascular complications (4). Furthermore, periodontal disease and consequent tooth loss could compromise the ability of patients to maintain a healthy diet (3).

Although alcohol is not considered a risk factor for periodontal disease, its consumption reduces the liver capacity to release glucose to the bloodstream and could cause hypoglycemia (6). Smoking is a risk factor for loss of alveolar bone, periodontal attachment and teeth (7). Due to their young age, few patients reported these habits.

Most diabetic children affirmed that their dentists were aware about their disease. This was a positive finding since dentists have an important role in preventing the development of oral problems related to T1DM. Koerber et al. (8) have recommend the development of dental consultation protocols and education about basic oral health as strategies for improving the oral health of individuals with T1DM.

Although the American National Institute of Health's "Healthy People 2010" program, which is a national disease prevention initiative that identifies opportunities to improve health status (3), recommends at 
least one visit annually for persons with diabetes, only half of the present population had this opportunity. The scarcity of dental services in the public health network

Table 1. Oral health perceptions and attitudes of the diabetics $(n=55)$ and control subjects $(n=55)$.

\begin{tabular}{|c|c|c|}
\hline \multirow{2}{*}{ Oral health habits } & \multicolumn{2}{|c|}{ Percentage $(\%)$} \\
\hline & Diabetics & Non-diabetics \\
\hline Cigarette smoking & 3.6 & 0 \\
\hline Consumption of alcoholic beverages & 7.2 & 10.9 \\
\hline Dentist visit at least once in the previous $12 \mathrm{mths}$. & 63.8 & 48.7 \\
\hline \multicolumn{3}{|l|}{ Reason for last visit } \\
\hline Checkup & 21.3 & 12.8 \\
\hline Cleaning & 34.0 & 46.2 \\
\hline Restoration & 31.9 & 23.1 \\
\hline Dental extraction & 6.4 & 17.9 \\
\hline Periodontal therapy & 0 & 0 \\
\hline Other & 6.4 & 0 \\
\hline \multicolumn{3}{|l|}{ Frequency of dental care } \\
\hline Enough & 34.5 & 38.2 \\
\hline Not enough & 65.5 & 61.8 \\
\hline \multicolumn{3}{|l|}{ Reason for not visiting the dentist more often } \\
\hline Transportation problems & 2.8 & 0 \\
\hline Fear or anxiety & 5.6 & 5.6 \\
\hline Forgot & 8.3 & 8.3 \\
\hline High costs & 27.8 & 13.9 \\
\hline Don't like my dentist & 0 & 2.8 \\
\hline Difficulty in scheduling appointment & 36.1 & 38.9 \\
\hline Cannot miss work & 0 & 2.8 \\
\hline Others & 19.4 & 27.8 \\
\hline \multicolumn{3}{|l|}{ Tooth brushing frequency } \\
\hline Less than once a day & 0 & 1.8 \\
\hline Once a day & 7.3 & 21.8 \\
\hline Twice a day & 34.5 & 21.8 \\
\hline Three times a day & 49.1 & 49.1 \\
\hline Four times a day & 5.5 & 0 \\
\hline More than four times a day & 3.6 & 5.5 \\
\hline Use of toothpaste & 100.0 & 98.2 \\
\hline Use of dental floss at least once a day & 30.9 & 18.2 \\
\hline Use of dental floss at least once a week* & 45.5 & 25.5 \\
\hline \multicolumn{3}{|l|}{ Rating of oral health } \\
\hline Very good & 7.3 & 7.3 \\
\hline Good & 74.5 & 72.7 \\
\hline Fair & 16.4 & 18.2 \\
\hline Poor & 0 & 1.8 \\
\hline Very Poor & 1.8 & 5.5 \\
\hline Gingival bleeding* & 27.3 & 54.5 \\
\hline Gingival bleeding with dental floss* & 16.4 & 40.0 \\
\hline Gingival bleeding during toothbrushing & 30.9 & 36.4 \\
\hline Spontaneous gingival bleeding* & 1.8 & 12.7 \\
\hline \multicolumn{3}{|l|}{ Health promotion priorities* } \\
\hline Exercise regularly & 14.5 & 7.3 \\
\hline Healthy diet & 41.8 & 30.9 \\
\hline Brush teeth regularly & 1.8 & 16.4 \\
\hline Visit a dentist regularly & 1.8 & 16.4 \\
\hline Visit a doctor regularly & 40.0 & 29.1 \\
\hline
\end{tabular}

$*$ Chi-square test $(\mathrm{p}<0.05)$. was the major reason for the difficulty of scheduling appointments. Dental consultations at private clinics were not a option for the children of the present study due to the high cost more than the half of dental treatment was provided by public services.

Moore et al. (3) described similar frequencies regarding the use of dentifrice and dental floss between diabetics and non-diabetics. In the present study, diabetics used dental floss more often than non-diabetics.

The reports of gingival bleeding with the use of dental floss, during toothbrushing or spontaneously, suggest the presence of gingivitis. As gingivitis is one of the early signs of periodontal disease, the patients must be warned about the need for dental assessment when this problem occurs. Surprisingly, in this study, gingival bleeding was more common in the non-diabetics.

None of the patients or their family members had ever participated in oral health program. Selli et al. (9) evaluated two groups of patients with diabetes mellitus, one of which participated in an interdisciplinary health assistance program and the other attended the program occasionally, and found improvement in all the studied variables (glycemia, weight, body mass index and blood pressure) in the group that adhered to the program.

Although diabetes is a risk factor for oral health complications $(10,11)$, this study showed lack of knowledge of basic oral health notions and difficult access to dental assistance in a population of children with T1DM followed up at a public health service facility in the city of Salvador, which is an important city of the northeast of Brazil. Since this was a subjective evaluation, further studies are needed to compare these data to those referring to the clinical oral health status. It would also be important to assess the oral health habits in other populations of Brazilian children with T1DM from similar background in order to support the implementation of oral public health policies in this area.

\section{RESUMO}

Este estudo avaliou o conhecimento das noções básicas de saúde bucal em crianças e adolescentes brasileiros com diabetes melito tipo 1 (DM1). Um estudo de corte transversal foi realizado entre novembro de 2005 e abril de 2006, em um serviço endocrinologia pediátrica de um hospital da rede pública, entrevistando 55 crianças diabéticas e 55 controle não-diabéticas. Um total de $55 \%$ dos diabéticos $(\mathrm{n}=55)$ e $35,5 \%$ dos não-diabéticos $(\mathrm{n}=$ 55) eram do gênero masculino com idade média de 11,3 $\pm 3,7$ e $11,2 \pm 3,8$ anos, respectivamente. A duração média do DM1 foi de 4,5 $\pm 0,8$ anos. Aproximadamente metade dos diabéticos e 
não-diabéticos escovava os dentes três vezes por dia. Fio dental era usado uma vez por dia por $30,9 \%$ dos diabéticos e $18,0 \%$ do grupo controle. Com relação à saúde periodontal, 27\% dos diabéticos relataram sangramento gingival contra $54,5 \%$ dos não-diabéticos. O dentista estava ciente do diagnóstico do DM1 em $74,5 \%$ dos casos. Dos diabéticos, $63,8 \%$ foram ao dentista nos últimos 12 meses. Conclui-se que apesar dos diabéticos aparentarem ter melhores hábitos de saúde oral do que os nãodiabéticos, ainda há necessidade de maiores informações sobre higiene oral e hábitos saudáveis.

\section{REFERENCES}

1. Siudikiene J, Machiulskiene V, Nyvad B, Tenovuo J, Nedzelskiene I. Dental caries and salivary status in children with type 1 diabetes mellitus, related to the metabolic control of the disease. Eur J Oral Sci 2006;114:8-14.

2. Löe H. Periodontal disease: the sixth complication of diabetes mellitus. Diabetes Care 1993;16:329-34.

3. Moore PA, Orchard T, Guggenheimer J, Weyant RJ. Diabetes and oral health promotion: a survey of disease prevention behaviors. JADA 2000;131:1333-1341.
4. Kinane DF, Peterson M, Stathopoulou PG. Environmental and other modifying factors of the periodontal diseases. Periodontol 2000 2006;40:107-119.

5. Herring ME, Shah SK. Periodontal disease and control of diabetes mellitus. J Am Osteopath Assoc 2006;106:416-21.

6. American Diabetes Association (ADA). Nutrition principles and recommendations in diabetes. Diabetes Care 2004;27:S36-S46.

7. Haber J, Wattles J, Crowley M, Mandell R, Joshipura K, Kent RL. Evidence for cigarette smoking as a major risk factor for periodontitis. J Periodontol 1992;64:16-23.

8. Koeber A, Peters KE, Kaste LM, Lopez E, Noorullah K, Torres I et al. The views of dentists, nurses and nutritionists on the association between diabetes and periodontal disease: a qualitative study in a Latino community. J Public Health Dent 2006;66:212-215.

9. Selli L, Papaléo LK, Meneghel SN, Jorneros JZ. Técnicas educacionales en el tratamiento de la diabetes. Cad Saúde Pública 2005;21:1366-1372.

10. Izquiredo E, Hernández-Mijares A. Type 1 diabetes mellitus and periodontal diseaee: relationship to different clinical variables. Med Oral Patol Cir Bucal 2009;14:E175-179.

11. Alves C, Andion J, Brandão M, Menezes R. Pathogenic aspects of periodontal disease related do diabetes mellitus. Arq Bras Endocrinol Metab 2007;51:1050-57. 